Quality of Academic Advising System

\title{
Perception of Nursing Students and Faculty Members of the Quality of Academic Advising System
}

\author{
Amira Maher Salem Mansour, Clinical instructor \\ Quality Assurance Unit, Faculty of Nursing, Alexandria University \\ Alice E. Reizian, Emeritus Professor \\ Medical Surgical Nursing, Faculty of Nursing, Alexandria University \\ Faten Abd El-Monem El Sebaey, Lecturer \\ Nursing Administration, Faculty of Nursing, Alexandria University
}

\begin{abstract}
Background: Academic advising can assist nursing students in understanding the purpose of the curriculum and to foster their intellectual and personal development toward academic success and lifelong learning. Therefore, the implementation of an academic advising program in nursing faculty based on the needs of students leads to promote their academic success at the faculty. Objective: This study aimed to determine the perception of nursing students and faculty members of the quality of academic advising system at the Faculty of Nursing, Alexandria University. Setting: Faculty of Nursing, Alexandria University. Subjects: The study subjects comprised undergraduate nursing students and nursing faculty members. Tool: Data was collected using a tool that included three parts, part I: Represents a continuum between the two contrasting advising. Part II: Measures the frequency of a particular activity taking place during advising sessions. Part III: Relates to various aspects of students and faculty members satisfaction with the advising received during the current academic semester. Results: the majority of studied baccalaureate nursing students perceived low level of quality of academic advising, while half of studied nursing faculty members perceived moderate level of quality of academic advising. Conclusion: the majority of the studied baccalaureate nursing students were advised by academic advisor who used prescriptive academic advising style. While half of the studied nursing academic advisor used developmental academic advising style to direct nursing students. Recommendations: Strengthen academic advisor orientation, training, and development through providing them with the essential components of the faculty advising system.
\end{abstract}




\section{Introduction}

Nowadays, higher education institutions are faced with highly competitive changes' some of these changes have resulted from multiple events including, increasing global competition, introducing of new technology and introducing quality in education to meet students and markets needs ${ }^{(1)}$. As a matter of fact, all of these can put a strong pressure on educational institutions for improving the quality of education and services offered ${ }^{(2,3)}$. Definitely, introducing the concepts of quality assurance and accreditation are coming more and more a center of attention of educational institutions ${ }^{(4)}$.

Actually, accreditation is a gateway towards total quality, and it is also considered to be a motivation for institutions to promote comprehensive educational processes and quality systems to raise the level of confidence in the institution and its graduates ${ }^{(5)}$. Since the international and national accreditation agencies NLNAC (2003), and the National Quality Assurance and Accreditation Agency for Higher Education (NAQAAE) in Egypt (2004) seeks to accredit all institutions that can demonstrate that they have met the published criteria ${ }^{(6)}$. In brief, the criteria requires the institution to have effective quality assurance systems that underpin the appropriate academic standards of its programs and the high quality of learning opportunities $^{(7)}$.

In this respect, Students and Graduates standard is one of the most important standards for accreditation by NAQAAE $^{(6,8)}$. It consists of more than one branch and the important branch is Student support ${ }^{(9)}$. It mainly depends on the facilities supplied to the students to gain success theses facilities include financial support, top students support, atrisk students support, health care and the core part of students support that enhances students self development and career achievements is academic advising ${ }^{(9,10)}$. Hence, Virginia et al. (2008) defines academic advising as student-centered process where students and academic advisors are partners in planning academic, personal, career goals and exchange information that empowers students to realize maximum educational potential, academic success, self-directed and life-long learning ${ }^{(11)}$.

Actually, the real birth of academic advising system in the 1979s established The National Academic Advising Association (NACADA) $)^{(12) .}$ "NACADA" is an organization comprised of professional and faculty advisors, administrators, students, and others with a 
Quality of Academic Advising System

primary interest in the practice of academic advising with diverse backgrounds, perspectives, and experiences ${ }^{(12)}$. Today, it is guided by the same purpose as it was 30 years ago: "to promote the quality of academic advising in institutions of higher education to enhance the educational development of students" $(12,13)$.

According to Roger (1984), the academic advising field has lacked a measurement tool that can be used to evaluate advising programs from a theoretically-grounded and allow comparisons across institutions ${ }^{(14) .}$ Therefore, Roger (1984) developed The Academic Advising Inventory (AAI) as a theoretically grounded measurement tool $^{(14) .}$ Moreover, AAI adapted by Winstor in (2002) and they cited three major parts of the academic advising inventory which are DevelopmentalPrescriptive advising Scale (DPA), Advisor-Advisee Activity Scale $(A A A)$ and Satisfaction with Advising ${ }^{(15) .}$

\section{Developmental - Prescriptive} advising Scale (DPA) is the first part of AAI. This scale was designed to assess two contrasting academic advising styles (prescriptive and developmental styles) of an actual advising situation ${ }^{(15)}$. In brief, two contrasting advising styles were published by Crookston (1972) ${ }^{(16)}$. $\mathrm{He}$ assumed Prescriptive styles as students are immature and irresponsible, and academic advisor instruct students on what to exactly do. On the other hand, $\boldsymbol{a}$ Developmental style assumes that academic advisor and student have equal authority and students are responsible for and capable of self -direction and should be the focus of the educational planning process $^{(16)}$. Moreover, DPA is composed of three dimensions: Personalizing Education (PE), Academic DecisionMaking (ADM) and Selecting Courses $(\mathrm{SC})^{(15)}$.

\section{Advisor-Advisee Activity Scale}

$(\boldsymbol{A A A})$ is the second part of AAI. This scale measures the frequency of a particular activity or behavior between students and academic advisor. This part is composed of five dimensions: Personal Development and Interpersonal Relationships (PDIR), Exploring Institutional Policies (EIP), Registration and Class Scheduling (RCS).Teaching Personal Skills (TPS) and Academic Majors and Courses (AMC) ${ }^{(15) .}$

\section{Satisfaction with advising scale is} the third part of AAI. This scale assesses students and faculty members' satisfaction with the advising during the current

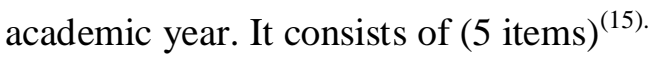

More broadly, academic advising can assist nursing students in 
understanding the purpose of the curriculum and to foster their intellectual and personal development toward academic success and lifelong learning ${ }^{(17) .}$ Therefore, the implementation of an academic advising program in nursing faculty based on the needs of students leads to promote their academic success at the faculty ${ }^{(18)}$.

Meanwhile, there is a strong acknowledgement that academic advising is a two-sided relationship ${ }^{(19)}$. Several researches in academic advising suggests that academic advising makes a meaningful difference in students' faculty experience and must be more than just the signing of registration forms, but also, sustained contact and interpersonal relationships are important factors in academic advising success and students'

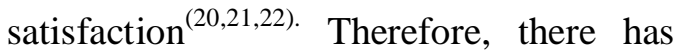
been sharing responsibilities between the academic advisor and advisee in the academic advising process ${ }^{(23) .}$

From this perspective academic advisors are responsible to inform students about university academic standards, policies, and procedures, assisting students in developing an educational plan consistent with students life goals, developing decision making skills, helping students in academic difficulties, referring students to important institution resources, building long-term interpersonal relationships with students, teaching students to become members of higher education community, think critically about roles and responsibilities as students and to prepare them to be educated citizens of a democratic society and a global community ${ }^{(23)}$. On the other hand, students are ultimately responsible to complete academic requirements in a timely manner, make regular progress appointments and also see advisor for assistance when questions or problems arise and prepare a list of desired and alternative courses prior to meetings with academic advisor $^{(24)}$.

\section{Aim of the Study}

Determine the perception of nursing students and faculty members of the quality of academic advising system.

\section{Research Question:}

What is the perception of nursing students and faculty members of the quality of academic advising system?

\section{Materials and Method}

\section{Materials}

Design: A descriptive research design was used. 
Setting: The study was carried out at the Faculty of Nursing, Alexandria University.

Subjects: The study subjects comprised undergraduate nursing students and nursing faculty members:

- Undergraduate nursing students included those who are enrolled in the fifth and seventh semesters, three hundred students $(n=300)$ who were available at the time of data collection they all have enough background about credit hours and process of academic advising system.

- $\quad$ Nursing faculty members in all the academic scientific departments at the Faculty of Nursing-Alexandria university seventy nursing faculty members $(n=70)$ who were available at the time of data collection. All of them have enough background and experience about credit hours and academic advising system.

Tool: One tool was used in this study:

Academic Advising Inventory (AAI):

The Academic Advising Inventory (AAI) was originally developed by Roger (1984) to assess the academic advising system. It includes 49 items and it consists of three parts, namely: The Developmental-Prescriptive advising
Scale (PDA), Advisor-Advisee Activity Scale $(A A A)$ and The Satisfaction with Advising $^{(14,15) \text {. }}$

Part I: The Developmental-Prescriptive advising Scale (DPA): it is composed of 14 pairs of statements. It represents a continuum between the two contrasting advising styles (prescriptive and developmental style) to describe the nature of the advising relationship and the breadth of topics and concerns addressed during advising sessions ${ }^{\circ}$ Also, It is composed of three dimensions: Personalizing Education (PE) (8 items), Academic Decision-Making (ADM) (4 items) and Selecting Courses (SC) (2 items $^{(15)}$.

Part II: Advisor-Advisee Activity Scale (AAA) it is composed of 30 statements which measure the frequency of a particular activity taking place during advising sessions ${ }^{(14,15)}$. This part composed of five dimensions: Personal Development and Interpersonal Relationships (PDIR) (12 items), Exploring Institutional Policies (EIP) (5 items), Registration and Class Scheduling (RCS) (4 items).Teaching Personal Skills (TPS) (3 items) and Academic Majors and Courses (AMC) (6 items $^{(14,15)}$. 


\section{Part III: the Satisfaction with Advising} that is related to various aspects of students and faculty members satisfaction with the advising that they have received during the current academic semester ${ }^{(15)}$. It consisted of (5 items) namely accuracy of information provided, adequacy of notice about important deadlines, availability of advisor when desired, and amount of time available during advising sessions ${ }^{(14)}$.

\section{Method}

1. Official permissions were obtained from the responsible authorities of the Faculty of Nursing, Alexandria University. These included the written approval obtained from the Dean Faculty of Nursing, Alexandria University and all head of the academic nursing department to collect the necessary data.

2. The tool (Academic Advising Inventory AAI) was translated into Arabic language then Arabic copy (for nursing students) and English copy (for nursing faculty members) were submitted to a jury of five experts from Faculty of Nursing, Alexandria University to test its content validity.

3. Tools were tested for reliability using the Cronbach's alpha coefficient to measure the internal consistency of the items. The Cronbach's $\alpha$ reliability coefficients for the first part The Developmental-Prescriptive advising Scale (PDA) was 0.742, for Advisor-Advisee Activity Scale (AAA) was 0.942, and for and The Satisfaction with Advising was 0.906. A cronbach's alpha tests were proved to be strongly reliable.

4. Before embarking on the actual study, a pilot study was carried out on nursing students $(\mathrm{N}=30)$, and nursing faculty members $(\mathrm{N}=75),(10 \%)$ of the sample size selected from study subjects at the Faculty of Nursing, Alexandria University that were not included in study sample. The purposes of the pilot study were to check and ensure the clarity of the translated tools, identify obstacles and problems that might be encountered during data collection, and to estimate the time needed to fill out the questionnaire.

5. The tool was distributed individually to the nursing students and nursing faculty members, and the researcher 
Quality of Academic Advising System

attended the students' and faculty members answering of the study tool to ensure that all information pertaining the questionnaire was completed. The data collection took a period of three months from 26/10/2012 to $30 / 1 / 2013$.

\section{Ethical considerations:}

Permission was obtained from all participants of the study after explanation of the study purpose and confidentiality of data was ensured.

\section{Statistical Analysis}

After completion of data collection, they were categorized, coded, computerized, tabulated and analyzed using frequency, percentage, minimum, maximum, arithmetic mean and standard deviation, f- test, $\mathrm{t}$ - test were used to test the significant association or variation between variables.

\section{Results}

Table (1.A) shows the distribution of the studied baccalaureate nursing students. Table1.A illustrates that, the greatest percentage of studied baccalaureate nursing students (63.3\%) were 20 years old, while the least percentage of them $(5.7 \%)$ were 19 years old. The majority of the studied baccalaureates nursing students (71.7\%) were females.

As regards the current academic semester, slightly more than one-half of studied baccalaureate nursing students $(57 \%)$ were registered in the seventh semester, while (43\%) of them were registered in the fifth semester. As related to students' last obtained Grade point Average (GPA), one third of the studied baccalaureate nursing students (31\%) obtained grade $\mathrm{B}$, followed by those who obtained B- (20.3\%). In relation to current nursing course students obtained in current semester, the highest percentage of studied baccalaureate nursing students $(17.7 \%)$ were registered in maternity and gynecology nursing course, while the least percentage of them $(12 \%)$ were registered in critical care nursing course.

Regarding the numbers of academic advising sessions students received in the current semester, the majority of the studied baccalaureate nursing students $(86 \%)$ received only one academic advising session in current semester. In relation to time of students spent in each academic advising session, the table 1.A shows that the majority of the studied baccalaureate nursing students (87\%) spent less than 15 minutes with academic 
advisor, while the minority of them $(0.7 \%)$ spent more than 1 hour with academic advisor in each academic advising session.

Table (1.B) shows the distribution of the studied nursing faculty members. Regarding age, the greatest percentage of the studied nursing faculty members $(27.1 \%)$ were in the age groups ranging from $30<40$ and $40<50$ years old, while the least percentage of them $(22.9 \%)$ were in the age groups $50<60$ and 60 or more years old. As regards academic position, the total number of the studied nursing faculty members was $70(100 \%)$ they were distributed as follows: (44.3\%) who represented greatest percentage were lecturers, followed by assistant. professors (22.9\%), while the least percentage of them $(11.4 \%)$ were full professors.

In relation to years of experience in academic field, half of the studied nursing faculty members (50\%) had 10-19 years of experience in academic field, while the least percentage of them $(18.6 \%)$ had 20 29 academic years of experience. Regarding scientific nursing department: The greatest percentage of studied nursing faculty members $(24.3 \%)$ were working in Medical \&Surgical Nursing Department, While the smallest percentage $(5.7 \%)$ of them were working in Nursing Education
Department and Gerontological Nursing Department.

As regards work as academic advisor in the faculty of nursing, the majority of studied nursing faculty members $(72.9 \%)$ were academic advisors, while the smallest percentage of them $(27.1 \%)$ didn't work as academic advisor. As related to years of experience as academic advisor in the faculty of nursing, slightly less than one-half of nursing faculty members $(45.7 \%)$ had 1-4years of experience as academic advisor, compared with $(27.1 \%)$ of studied nursing faculty members who didn't have any experience as academic advisor.

In relation to number of students assigned to academic advisor, table1.B shows that the majority of studied nursing faculty members who work as academic advisor (37.1\%) were assigned 20-25 students, followed by (21.4\%) of them assigned to more than 26 nursing students, compared with $(27.1 \%)$ of faculty members who didn't work as academic advisor. Regarding receiving academic advising training, slightly more than one-half of studied nursing faculty members (52.9\%) attended workshops about academic advising system, while $(47.1 \%)$ of them didn't receive any academic advising training. 
Table (2) illustrates the Perception of the studied baccalaureate nursing students and the studied nursing faculty members towards three parts of the academic advising inventory (AAI). In relation to the first part (Developmental prescriptive advising scale) table 2 indicates that the total mean percent score of the studied baccalaureate nursing students' perception was lower than the total mean percent score of the studied nursing faculty members' perception $52.98 \pm 11.98$, $60.65 \pm 19.25$ respectively. There was a statistical significant difference observed between total mean percent score of the studied baccalaureate nursing students and the studied nursing faculty members perception towards the three dimensions of first part developmental prescriptive advising scale $(\mathrm{t}=3.191, \mathrm{p}=0.002)$.

\section{Regarding the second part (advisor} advisee activity scale), the same table points out the total mean percent score of the studied baccalaureate nursing students' as perception was lower than the total mean percent score of the studied nursing faculty members' perception $24.85 \pm 9.50,43.79 \pm 17.98$ respectively. There was a highly statistical significant difference observed between total mean percent score of the studied baccalaureate nursing students and the studied nursing faculty members perception towards the five dimensions of second part advisor advisee activity scale $\quad(\mathrm{t}=8.537$, $\mathrm{p}=<0.001)$.

As regard the third part (satisfaction with advising), table 2 also illustrated that the total mean percent score of the studied baccalaureate nursing students perception was lower than the total mean percent score of the studied nursing faculty members perception 24.42 \pm 23.56 , $46.38 \pm 26.65$ respectively. There was a highly statistical significant difference observed between total mean percent score of the studied baccalaureate nursing students and the studied nursing faculty members' perception in relation to satisfaction with advising $(\mathrm{t}=6.844$, $\mathrm{p}=<0.001)$.

Table (3) shows the quality academic advising levels as perceived by the studied baccalaureate nursing students and the studied nursing faculty members. In relation to studied baccalaureate nursing students' table $\mathbf{3}$ illustrates that the majority of studied baccalaureate nursing students $(90.7 \%)$ perceived low level of quality of academic advising, while the minority of them $(0.7 \%)$ perceived high level of quality of academic advising.

In relation to the studied nursing faculty members the same table illustrated that, half of studied nursing faculty members $(50 \%)$ perceived moderate level 
of quality of academic advising, while $(40 \%)$ of them perceived low quality of academic advising .There was a highly statistical significant difference between the studied baccalaureate nursing students and the studied nursing faulty members regarding their perception toward quality of academic advising levels $(\chi 2=97.111$, $\mathrm{p}=<0.001)$.

Table (4) shows the relationship between demographic characteristics of the studied baccalaureate nursing students and their perception of quality of academic advising level. Table 4 this table illustrates that there were statistical significant relationships between all demographic characteristics of the studied nursing students and quality of academic advising level except for current academic semester and current nursing course students obtained in current semester where $\mathrm{P}=0.084$, and 0.113 respectively .

According to age, it was found that the majority of the studied baccalaureate nursing students $(65 \%)$ who are 21 years old had low quality of academic advising. Regarding gender, the majority of female nursing students (73.9\%) had low quality of academic advising.

As related to current academic semester, the highest percentage of the studied baccalaureate nursing students $(55.1 \%)$ who were registered in seventh semester reported low quality of academic advising, whereas (53.8\%) of them perceived moderate quality of academic advising.

Concerning Students' last obtained GPA, half of the studied baccalaureate nursing students (50\%) who obtained grade A and A- evaluate their quality of academic advising as high.

As related to current nursing course students obtained in current semester, half of the studied baccalaureate nursing students $(50 \%)$ who were registered in Pediatric nursing course, Nursing administration course reported high level of quality academic advising.

Concerning numbers of academic advising sessions students received in the current semester, the majority of the studied baccalaureate nursing students $(89.3 \%)$ who received only one academic advising session evaluated their quality of academic advising as low.

As related to time spent by nursing students spent in each academic advising session, the highest percentage of the studied baccalaureate nursing students (90.4\%) spent less than 15 minutes with academic advisor those students reported low quality of academic advising.

Table (5) shows the relationship between demographic characteristics of 
the studied nursing faculty members and their perception of quality of academic advising level. Table 5 illustrates that, there were statistical significant relationships between socio demographic characteristics of the studied nursing faculty members and quality of academic advising level in the term of work as academic advisor, years of experience as academic advisor, and number of students assigned to you for advising where $\mathrm{p}=(0.001,0.001,0.003)$ respectively.

According to age, the majority of the studied nursing faculty members $(57.1 \%)$ who were more than 60 years old perceived high quality of academic advising, while $(32.1 \%)$ of them who were in age group " $40<50$ ”years old perceived that quality of academic advising was low. Regarding academic position, slightly more than half $(57.1 \%)$ of professors emeritus perceived that quality of academic advising was high, while $(46.4 \%)$ of lecturers perceived that quality of academic advising as low.

As related to academic years of experience, the majority (71.4\%) of the studied nursing faculty members with duration of academic experience more than 30 years perceived their quality of academic advising as high, While (57.1\%) of the studied nursing faculty members with academic experience ranging from
$10-19$ years evaluated their quality of academic advising as low.

Regarding scientific nursing departments, the highest percentage of the studied nursing faculty members $(31.4 \%)$ who were working in medical surgical department reported moderate quality of academic advising.

Concerning work as academic advisor in the faculty of nursing, the highest percentage of the studied nursing faculty members (88.6\%) who worked as academic advisors had moderate level of quality of academic advising .while $(53.6 \%)$ of nursing faculty members didn't work as academic advisor had low quality of academic advising.

As related to years of experience as academic advisor in the faculty of nursing ,the majority of academic advisors (57.1\%) had experience ranging from 5 or more years perceived high quality of academic advising, whereas those academic advisors who had experience ranging from " $1-4$ " years perceived moderate quality of academic advising.

In relation to number of students assigned to academic advisor, (57.1\%) of studied nursing faculty members who worked as academic advisor and were assigned less than 20 nursing students evaluated their quality of academic 
advising as high followed by those who were assigned 20-25 nursing students $(45.7 \%)$ evaluated their quality of academic advising as moderate quality. compared with $(53.6 \%)$ of faculty members who didn't work as academic advisors and were not assigned with students who perceived low quality of academic advising.

Concerning nursing faculty members receiving academic advising training about $(85.7 \%)$ of studied nursing faculty members attended workshops about academic advising system perceived high quality of academic advising. On the other hand, $(60.7 \%)$ of those who didn't received academic advising training perceived low quality of academic advising.

\section{Discussion}

In relation to developmental prescriptive advising: The finding of the present study showed that the perception of the studied baccalaureate nursing student's toward their developmental prescriptive advising dimensions (DPA) was lower than the perception of the studied nursing faculty members' at the Faculty of Nursing-Alexandria University with a statistical significant difference. This result may be attributed to that limited involvement between nursing students and academic advisors that may lead to academic advisors accepting the major portion of the responsibility to direct nursing students without talking with them about their interests, concerns and non academic and academic plans. Therefore, many decisions are made by the academic advisor such as diagnosing the nursing student's problems, choosing courses, planning students' schedules, and giving detailed instructions to nursing students and making sure that they follow through.

This finding goes in line with the finding of Murrill (2005) who found that students perceive faculty members as superiors, competent and trustworthy to direct students on what to exactly do ${ }^{(25)}$. However, the finding of the present study is inconsistent with Boyle (2002) who mentioned that advisors must rarely make decisions for students, encourage students to ask open-ended questions, use faculty resources to find answers, and plan courses of study and schedules around the outcomes of their explorations ${ }^{(26)}$.

In relation to advisor advisee activity: The findings of the present study revealed that the perception of the studied baccalaureate nursing students' toward their advisors advisees activity was lower than the perception of the studied nursing 
faculty members' with a statistical significant difference. This may be attributed to that the most of the studied baccalaureate nursing students have less frequent contact with their academic advisors that may lead to decreased acquaintance of the most important activities that nursing students take place during advising sessions such as talking with academic advisors about experience in different classes to evaluate of nursing students academic progress, identifying the available times and places of academic advisor and discussing extracurricular activities. This finding is in agreement with the finding of Broadbridge, (2000) who viewed that academic advising relation is just a peripheral part of the academic administrative function, limits relation and advisor activity for providing information about courses, explaining registration procedures, and ensuring students enroll in appropriate courses, thereby, permitting very little student control or decision-making power ${ }^{(27)}$. On the contrary, White (2000) found that frequent contact and increase academic advising sessions lead to increase student retention and satisfaction in educational institution $^{(28)}$.

In relation to satisfaction with advising: The present study findings revealed that the perception of the studied baccalaureate nursing students' was lower than the studied nursing faculty members' perception of their satisfaction with advising at the Faculty of NursingAlexandria University with a statistical significance difference. This could be explained in the light of our findings in which most of the studied baccalaureate nursing students were advised by prescriptive academic advising style that lead to that most of them view their academic advisors with authorities relationship and don't spent sufficient time during advising sessions which may compromise their ability to become integrated into faculty life, develop mentoring relationships, or develop a sense of belonging within the institution, all these factors lead to decreased nursing students satisfaction toward academic advising system in faculty of nursing.

This finding is congruent with Kuhn \& Padak (2008) who reported that the authoritative approach makes advisors and advisees feel competent and supported to face the challenges of faculty because the authoritative advisor is one who is confident, knowledgeable, and communicates to students a sense of calmness, steadiness, and assuredness to help students orient and acclimate to faculty $^{(29)}$. 
The present study demonstrated that the majority of the studied baccalaureate nursing students perceived low level of quality of academic advising at the Faculty of Nursing, Alexandria University. This finding may be related to many reasons; Firstly, many of the advising problems stem from registration difficulties such as there is no deadline for the beginning and end of the registration process and lack channel of communication among nursing students, academic advisor, and students affairs department at nursing faculty. Secondly, nursing students come to their advisors without preparing list of pervious and offered academic courses, and their last Grade Point Average (GPA) to determine what courses are most appropriate for students to take. Thirdly, it is important for advisors to develop working relationships with students but with large numbers of advisees, advisors cannot play a mentoring role. Finally, lack of training for designated individuals who are accountable for assessing academic advising (academic advisor, nursing students) related to importance, goals, steps of registration process, and responsibilities of faculty, academic advisor, and students about credit hours and academic advising system.
The study findings are matched with the findings of Andrepont (2005) who found that inadequate academic advising is an obstacle to obtaining a bachelor's degree $^{(30)}$. On the other hand, Carey (2008) contradicted with the result of this study and they found that high quality of academic advising is the single most powerful predictor of satisfaction with the faculty environment ${ }^{(31)}$.

On the other hand, the present study demonstrates that the half of the studied nursing faculty members perceived moderate level of quality of academic advising at Faculty of Nursing, Alexandria University. This finding may be related to many reasons; Firstly, increase of nursing faculty members' workload .Secondly, limited number of the teaching staff to provide academic advising services to nursing students that lead to decrease ability of academic advisor to follow up nursing students and did not give them sufficient guidance to maintain effective advising system. Thirdly, advisors have complained that the present number of advisees per advisor, in many cases, is unmanageably large and that there was severe inequity in distribution of nursing students among advisors. Finally, new faculty members didn't have a chance to attend at least one training session prior to assuming their 
first advising assignment. This finding of the present study is supported by McClellan (2007) who reported that faculty members in their study had a moderate level of quality of academic advising and the faculty members are commitment to helping students understand the importance of getting a high quality experience of academic $\operatorname{advising}^{(32) \text {. }}$

Moreover, it was clear from the present study finding that there was low level of quality of academic advising as perceived by nursing students among nursing students with age 21 years old and registered in seventh semester. It may be due to that nursing students above twenty years old and registered in seventh semester are considered in third and fourth academic year in nursing faculty. These students are near to be graduated from nursing faculty. Therefore, the aim is not only to learn but also to graduate from the faculty, so they needed to finish of academic requirements without emphasis on the relation with faculty members because they need to register academic courses only. This finding was supported by Mayhall \& Burg (2002) they found that older students understand the academic and administrative processes of the university, have enough experience about academic advising system and way of register of academic courses so older student less frequent contact with academic advisors ${ }^{(33)}$. This finding is inconsistent with the view of Bloom et al (2008) who found that advisors can use developmental academic advising style to encourage oldest students to raise their expectations of themselves and to build on past successes to achieve even greater levels of success in the future ${ }^{(34) .}$.

In addition, the results of the current study reported that there is low level of quality of academic advising among male nursing students. It may be contributed to that lack of male nursing students' involvement with nursing faculty members which could lead them to feel less commitment and belongingness to their faculty. Therefore, male students are emphasized on registration of academic courses only. This finding is supported by Nadler (2002) who founded that women prefer more social support from supervisors than men ${ }^{(35)}$ On other contrary, Schulenberg, \& Lindhorst, (2008) found that men rate themselves at a higher level of performance than women prior to register of academic courses and meet with academic advisors ${ }^{(36)}$.

The studied baccalaureate nursing students' in the present study, high level of quality of academic advising especially among nursing student whose their last 
obtained GPA was "A". These results may be due to that the help provided by the academic advisors in each academic semester to support of top nursing students in nursing faculty. They guide and prepare top students to deal effectively with their difficulties (academic and non academic problems) and identify information about academic courses to achieve optimal academic achievements. These preparations provided by academic advisors empower top nursing students to be more satisfied, competent, and motivated them to obtain high achievements score in each academic semester. These findings of the present study is parallel to Drake (2011) who argued that academic advisors are more interested with students obtained highest GPA in different academic class to keep their level of academic achievements and to be more creative ${ }^{(37)}$. On the other hand, These findings are inconsistent with Tahmoures \& Leo (2006) they concluded that students with the lowest GPAs rated having an advisor willing to discuss personal problems as important and those with the highest GPAs preferred a friendly advisor $^{(38) \text {. }}$

The findings of the present study revealed that that there is high quality of academic advising especially among nursing students registered in pediatric nursing course. This could be attributed to nursing faculty members who work for this department may believe that the work which they are doing is important and they have high level of sensitivity because they deal with children. Therefore, their tasks are meaningful and need effective academic advising. The finding of the present study is congruent with Glennen (2005) who found that the nature of work itself has been the central determinants of academic advising style ${ }^{(39) .}$

The finding of the present study indicated that there is low level of quality of academic advising especially among nursing students received only one academic advising session and spent less than 15 minutes with academic advisor. This could be attributed to the fact that the limited numbers of academic advising sessions did not give opportunity to nursing students to understand advising as a system in nursing faculty and summarized academic advising system in registration process only. Moreover, insufficient time available during advising sessions did not allow academic advisor to provide accurate information to nursing students about deadlines for the beginning and end of the registration process, electives, prerequisites academic courses, discuss the rules and policies of academic advising system, such as the maximum 
and minimum number of registered credit hour and discuss the vision, mission and goals of the faculty and it is fit with the requirements of the credit hour system This finding is consistent with Trombley (2009) who proposed that restriction of academic advising sessions may have affected their academic advising process $^{(40)}$.

The present study pointed out that there is high level of quality of academic advising as perceived by nursing faculty members .In favor among nursing faculty members with age group 60 or more years old and who had academic years of experience that ranged from 30 and more years. This result could be understood according to the fact that older nursing faculty members feel stable, secure and have more realistic job expectations or perhaps they perceive fewer external work options. They also, tend to be longer tenured and to have reached higher levels within their faculty. All these factors lead to older nursing faculty members used the developmental style because an advisor must enter into a partnership with advisee and go beyond ensuring that the student is choosing coursework. Also, they serve as facilitators of communication, coordinators of learning experiences through course and academic progress review, and agents of referral to other faculty agencies as necessary. Moreover, older nursing faculty members' skills in academic advising system increase with years of experience due to their familiarity with duties and roles in advising and registration process. They become more knowledgeable and more able to solve problems and conflicts that faced their nursing students. In this respect, Stull (2008) found that the relatively oldest faculty members are more likely to be effective advisor than relatively youngest $^{(41) .}$ In addition, this finding is in agreement with McLaren, (2004) who stated that the higher aged faculty members who had been with the organization longer and who had been higher position in this organization tend to score higher level of academic $\operatorname{advising}^{(42) \text {. }}$

The finding of the present study indicated that there is high level of quality of academic advising in favor among emeritus professor position. This might be attributed to that older faculty members got more experiences, attended and shared in many activities that lead to gain high experience in teaching and increase self confidence due to accumulative knowledge about academic advising system in faculty. This result is supported by Wyckoff (2012) who found that older faculty members have increase knowledge 
of them helps to improve academic advising in educational institution ${ }^{(43)}$.

The findings of the present study indicated that there is high level of quality of academic advising. in favor, among nursing faculty members who had years of experience as academic advisor that ranged from 5 and more years. This could be attributed to that the increased years of experience so the academic advisors have increased sense of confidence and competence about academic advising and registration process and become competent in dealing with nursing students to registered appropriate courses .In addition they discussed advisees in the academic and non academic activities and goals which facilitate building relation with advisee and sharing knowledge and ideas. This could be attributed to that the nursing faculty members who have high experience have self confidence that due to the accumulative knowledge in different aspect in teaching filed and academic advising experiences which were provided by the experience they gained along their career life leading to make them able to chose aright advising style to deal with nursing students. This finding is the same line with Miller (2009) who stated that academic advisors with long experiences are more committed to their work because they had more conformity with the work ,more capable to take decisions, and more trust and powerful and they feel trust between themselves and the management system of their faculty ${ }^{(44)}$.

However, the findings of the present study indicated that there is high level of quality of academic advising. Especially among academic advisors who are assigned less than 20 nursing students'. It may be due to that limited number of the nursing students assigned with academic advisor lead to maintain effective advising system and sufficient social and communication skills to work well with others and communicate ideas to a group. This finding was supported by Schreiner\& Anderson (2005) they found that the number of teaching staff and facultystudent interaction demonstrated meaningful effects on student collegiate outcomes. These outcomes included intellectual growth, career development and scientific reasoning ${ }^{(45)}$.

\section{Conclusion}

Based on the results of this study one can conclude that, the majority of the studied baccalaureate nursing students were advised and directed by academic advisor who used prescriptive academic advising style. While half of the studied 
Quality of Academic Advising System

nursing academic advisor used developmental academic advising style to direct nursing students. Also, the findings of this study revealed that the total mean percent score of the studied baccalaureate nursing students' perception of the developmental prescriptive advising scale, advisor advisee activity scale, and satisfaction with advising were lower than the total mean percent score of the studied nursing faculty members' perception with statistical significant difference detected towards these parts.

\section{Recommendations}

In the light of the results of this study, the following recommendations are suggested:

1. Regularly assess and evaluate the quality of academic advisement at the Faculty of Nursing Alexandria University.

2. Strengthen advisor orientation, training, and development, and deliver them as essential components of the institution's faculty/staff development program.

3. Maintain advisee-to-advisor ratios that are small enough to enable delivery of advising and fair distribution of students to academic advisor.

4. Introduction of an advanced or electronic system such as (on- line registration program) which use computers and internet to facilitate registration process. 
Table (1.A): Demographic Characteristics of the Studied Baccalaureate Nursing Students at the Faculty of Nursing - Alexandria University

\begin{tabular}{|c|c|c|c|}
\hline \multicolumn{2}{|c|}{ Demographic characteristics (nursing students=300) } & \multirow{2}{*}{$\begin{array}{l}\text { No } \\
17\end{array}$} & \multirow{2}{*}{$\begin{array}{l}\% \\
5.7\end{array}$} \\
\hline \multirow{3}{*}{ Age(years): } & 19 & & \\
\hline & 20 & 190 & 63.3 \\
\hline & 21 & 93 & 31.0 \\
\hline \multirow[t]{2}{*}{ Gender : } & Male & 85 & 28.3 \\
\hline & Female & 215 & 71.7 \\
\hline \multirow[t]{2}{*}{ Current academic semester : } & the fifth & 129 & 43.0 \\
\hline & the seventh & 171 & 57.0 \\
\hline \multirow[t]{9}{*}{ Students last obtained GPA: } & A & 2 & 0.7 \\
\hline & A- & 3 & 1.0 \\
\hline & $\mathrm{B}+$ & 35 & 11.7 \\
\hline & $\overline{\mathrm{B}}$ & 93 & 31.0 \\
\hline & B- & 61 & 20.3 \\
\hline & $\mathrm{C}+$ & 60 & 20.0 \\
\hline & $\mathrm{C}$ & 33 & $\overline{11.0}$ \\
\hline & C- & 12 & 4.0 \\
\hline & $\mathrm{D}+$ & 1 & 0.3 \\
\hline \multirow{7}{*}{$\begin{array}{l}\text { Current nursing course students } \\
\text { obtained in current semester: }\end{array}$} & critical care nursing & 36 & 12.0 \\
\hline & pediatric nursing & 40 & 13.3 \\
\hline & maternity and gynecology nursing & 53 & 17.7 \\
\hline & community health nursing & 46 & 15.3 \\
\hline & gerontological nursing & 46 & 15.3 \\
\hline & psychiatric and mental health nursing & 39 & 13.0 \\
\hline & nursing administration & 40 & 13.3 \\
\hline \multirow{7}{*}{$\begin{array}{l}\text { Numbers of academic advising } \\
\text { sessions students received in the } \\
\text { current semester : }\end{array}$} & None & 2 & 0.7 \\
\hline & One & 258 & 86.0 \\
\hline & Two & 19 & 6.3 \\
\hline & Three & 12 & 4.0 \\
\hline & Four & 2 & 0.7 \\
\hline & Five & 3 & 1.0 \\
\hline & Six & 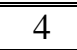 & $\overline{1.3}$ \\
\hline \multirow{3}{*}{$\begin{array}{l}\text { Time of students spent in each } \\
\text { academic advising session: }\end{array}$} & less than 15 minutes & 261 & 87.0 \\
\hline & $15-30$ minutes & 37 & 12.3 \\
\hline & more than 1 hour & 2 & 0.7 \\
\hline
\end{tabular}


Table (1.B): Demographic Characteristics of the Studied Nursing Faculty Members at the Faculty of Nursing - Alexandria University.

\begin{tabular}{|c|c|c|c|}
\hline \multicolumn{2}{|c|}{ Demographic characteristics (nursing faculty members=70) } & No & $\%$ \\
\hline \multirow{4}{*}{ Age (years): } & $30<40$ & 19 & 27.1 \\
\hline & $40<50$ & 19 & 27.1 \\
\hline & $50<60$ & 16 & 22.9 \\
\hline & 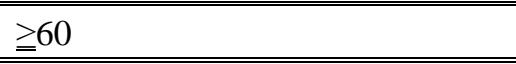 & 16 & 22.9 \\
\hline \multirow[t]{4}{*}{ Academic position: } & professor emeritus & 15 & 21.4 \\
\hline & Professor & 8 & 11.4 \\
\hline & assistance professor & 16 & 22.9 \\
\hline & Lecturer & 31 & 44.3 \\
\hline \multirow[t]{3}{*}{ Academic years of experiences : } & $10-19$ & 35 & 50.0 \\
\hline & $20-29$ & 13 & 18.6 \\
\hline & $30+$ & 22 & 31.4 \\
\hline \multirow[t]{9}{*}{ Area of specialty:(your department) } & medical surgical nursing & 17 & 24.3 \\
\hline & critical care nursing & 6 & 8.6 \\
\hline & nursing education & 4 & 5.7 \\
\hline & pediatric nursing & 8 & 11.4 \\
\hline & maternity and gynecology nursing & 8 & 11.4 \\
\hline & community health nursing & 10 & 14.3 \\
\hline & gerontological nursing & 4 & 5.7 \\
\hline & $\begin{array}{l}\text { psychiatric and mental health } \\
\text { nursing }\end{array}$ & 7 & 10.0 \\
\hline & nursing administration & 6 & 8.6 \\
\hline \multirow{2}{*}{ are you an academic advisor: } & Yes & 51 & 72.9 \\
\hline & No & 19 & 27.1 \\
\hline \multirow{3}{*}{$\begin{array}{l}\text { Years of experiences as academic } \\
\text { advisor: }\end{array}$} & None & 19 & 27.1 \\
\hline & $1-4$ & 32 & 45.7 \\
\hline & $5+$ & 19 & 27.1 \\
\hline \multirow{4}{*}{$\begin{array}{r}\text { Number of students assigned to } \\
\text { academic advisor : }\end{array}$} & None & 19 & 27.1 \\
\hline & $<20$ & 10 & 14.3 \\
\hline & $20-25$ & 26 & 37.1 \\
\hline & $26+$ & 15 & 21.4 \\
\hline \multirow{2}{*}{$\begin{array}{l}\text { Received academic advising training } \\
\text { "work shop": }\end{array}$} & yes & 37 & 52.9 \\
\hline & No & 33 & 47.1 \\
\hline
\end{tabular}


Table (2): Perception of the Studied Baccalaureate Nursing Students and the Studied Nursing Faculty Members Towards Three Parts of the Academic Advising Inventory (AAI).

\begin{tabular}{|c|c|c|c|c|}
\hline \multirow{2}{*}{$\begin{array}{l}\text { Academic Advising } \\
\text { Inventory } \\
\text { (AAI) }\end{array}$} & $\begin{array}{l}\text { Nursing Students } \\
\qquad(\mathbf{N}=\mathbf{3 0 0})\end{array}$ & $\begin{array}{l}\text { Nursing faculty } \\
\text { members } \\
(\mathrm{N}=70)\end{array}$ & \multirow[t]{2}{*}{$\mathbf{t}$} & \multirow[t]{2}{*}{$\mathbf{p}$} \\
\hline & Mean \% score \pm SD. & Mean $\%$ score \pm SD. & & \\
\hline \multicolumn{5}{|c|}{ The first part ( Developmental prescriptive advising) dimensions } \\
\hline Personalizing education & $40.76 \pm 12.81$ & $60.83 \pm 18.91$ & 8.438 & $<0.001^{* * *}$ \\
\hline Academic decision-making & $60.71 \pm 18.44$ & $57.28 \pm 23.77$ & 1.132 & 0.261 \\
\hline Selecting courses & $58.0 \pm 17.19$ & $63.84 \pm 27.06$ & 1.726 & 0.088 \\
\hline $\begin{array}{l}\text { Total (Developmental } \\
\text { prescriptive advising) }\end{array}$ & $52.98 \pm 11.98$ & $60.65 \pm 19.25$ & 3.191 & $0.002^{*}$ \\
\hline \multicolumn{5}{|c|}{ The second part ( Advisor advises activity scale) dimensions } \\
\hline Personal development & $8.07 \pm 9.84$ & $35.16 \pm 21.17$ & 10.451 & $<0.001^{* *}$ \\
\hline $\begin{array}{c}\text { Exploring institutional } \\
\text { policies }\end{array}$ & $5.55 \pm 10.31$ & $25.37 \pm 20.32$ & 7.930 & $<0.001^{* *}$ \\
\hline $\begin{array}{l}\text { Registration and class } \\
\text { scheduling }\end{array}$ & $16.28 \pm 15.04$ & $39.57 \pm 30.40$ & 6.233 & $<0.001^{* * *}$ \\
\hline Teaching personal skills & $3.96 \pm 10.83$ & $32.86 \pm 28.52$ & 8.340 & $<0.001^{* *}$ \\
\hline $\begin{array}{c}\text { Academic majors and } \\
\text { courses }\end{array}$ & $5.93 \pm 13.32$ & $32.81 \pm 25.35$ & 8.597 & $<0.001^{* * *}$ \\
\hline $\begin{array}{c}\text { Total (Advisor advises } \\
\text { activity scale) }\end{array}$ & $24.85 \pm 9.50$ & $43.79 \pm 17.98$ & 8.537 & $<0.001^{* * *}$ \\
\hline \multicolumn{5}{|c|}{ The third part( Satisfaction with advising) } \\
\hline Satisfaction with advising & $24.42 \pm 23.56$ & $46.38 \pm 26.65$ & 6.844 & $<0.001^{* * *}$ \\
\hline
\end{tabular}

t: Student t-test

$\mathrm{P}>0.05 \Rightarrow$ Not significant, $* \leq 0.05 \Rightarrow$ significant, $* * \leq 0.01 \Rightarrow$ highly significant 
Table (3): Quality Academic Advising Levels as Perceived by the Studied Baccalaureate Nursing Students and the Studied Nursing Faculty Members at the Faculty of Nursing Alexandria University.

\begin{tabular}{|c|c|c|c|c|c|c|}
\hline \multirow{2}{*}{$\begin{array}{c}\text { Quality of academic } \\
\text { advising } \\
\text { Level }\end{array}$} & \multicolumn{2}{|c|}{$\begin{array}{c}\text { Nursing } \\
\text { Students }(n=300) \\
\end{array}$} & \multicolumn{2}{|c|}{$\begin{array}{l}\text { Nursing faculty } \\
\text { members }(n=70)\end{array}$} & \multirow{2}{*}{$\chi^{2}$} & \multirow{2}{*}{$\mathbf{p}$} \\
\hline & No. & $\%$ & No. & $\%$ & & \\
\hline Low & 272 & 90.7 & 28 & 40.0 & \multirow{3}{*}{97.111} & \multirow{3}{*}{$<0.001^{*}$} \\
\hline Moderate & 26 & 8.7 & 35 & 50.0 & & \\
\hline High & 2 & 0.7 & 7 & 10.0 & & \\
\hline
\end{tabular}

$\chi^{2}$ : Chi square test

$\mathrm{P}>0.05 \Rightarrow$ Not significant, $* \leq 0.05 \Rightarrow$ significant, $* * \leq 0.01 \Rightarrow$ highly significant 
Quality of Academic Advising System

Table (4): The Relationship Between the Socio- Demographic Characteristics of the Studied Baccalaureate Nursing Students and their Perception of Quality of Academic Advising Level.

\begin{tabular}{|c|c|c|c|c|c|c|c|c|}
\hline \multirow{3}{*}{\multicolumn{2}{|c|}{ "Socio-demographic characteristics }} & \multicolumn{7}{|c|}{ Quality of academic advising levels } \\
\hline & & \multicolumn{2}{|c|}{ Low (272) } & \multicolumn{2}{|c|}{$\begin{array}{c}\text { Moderate } \\
\text { (26) }\end{array}$} & \multicolumn{2}{|c|}{ High (2) } & \multirow{2}{*}{$\begin{array}{c}\text { Test of } \\
\text { significance }\end{array}$} \\
\hline & & No. & $\%$ & No. & $\%$ & No. & $\%$ & \\
\hline \multirow{3}{*}{ Age (years): } & 19 & 17 & 6.3 & 0 & 0.0 & 0 & 0.0 & \multirow{3}{*}{${ }^{\mathrm{Mc}} \mathrm{p}=0.032$} \\
\hline & 20 & 78 & 28.7 & 13 & 50.0 & 1 & 50.0 & \\
\hline & 21 & 177 & 65 & 13 & 50.0 & 1 & 50.0 & \\
\hline \multirow[t]{2}{*}{ Gender: } & Male & 71 & 26.1 & 13 & 50.0 & 1 & 50.0 & \multirow[t]{2}{*}{${ }^{\mathrm{Mc}} \mathrm{p}=0.014$} \\
\hline & Female & 201 & 73.9 & 13 & 50.0 & 1 & 50.0 & \\
\hline \multirow{2}{*}{$\begin{array}{l}\text { Current academic } \\
\text { semester: }\end{array}$} & the fifth & 122 & 44.9 & 12 & 46.1 & 1 & 50.0 & \multirow[t]{2}{*}{${ }^{\mathrm{Mc}} \mathrm{p}=0.084$} \\
\hline & he seventh & 150 & 55.1 & 14 & 53.8 & 1 & 50.0 & \\
\hline \multirow{9}{*}{$\begin{array}{l}\text { Students last obtained } \\
\text { GPA: }\end{array}$} & $\mathbf{A}$ & 1 & 0.4 & 0 & 0.0 & 1 & 50.0 & \multirow{9}{*}{${ }^{\mathrm{Mc}} \mathrm{p}=0.006$} \\
\hline & A - & 2 & 0.7 & 0 & 0.0 & 1 & 50.0 & \\
\hline & $\mathbf{B +}$ & 29 & 10.7 & 6 & 23.1 & 0 & 0.0 & \\
\hline & B & 89 & 32.7 & 4 & 15.4 & 0 & 0.0 & \\
\hline & B - & 53 & 19.5 & 8 & 30.8 & 0 & 0.0 & \\
\hline & $\mathrm{C}+$ & 54 & 19.9 & 6 & 23.1 & 0 & 0.0 & \\
\hline & $\mathbf{C}$ & 31 & 11.4 & 2 & 7.7 & 0 & 0.0 & \\
\hline & $\mathrm{C}$ - & 12 & 4.4 & 0 & 0.0 & 0 & 0.0 & \\
\hline & D+ & 1 & 0.4 & 0 & 0.0 & 0 & 0.0 & \\
\hline \multirow{6}{*}{$\begin{array}{l}\text { Current nursing course } \\
\text { students obtained in } \\
\text { current semester }\end{array}$} & Critical care nursing & 35 & 12.9 & 1 & 3.8 & 0 & 0.0 & \multirow{6}{*}{${ }^{\mathrm{Mc}} \mathrm{p}=0.113$} \\
\hline & Pediatric nursing & 35 & 12.9 & 5 & 19.2 & 1 & 50.0 & \\
\hline & $\begin{array}{l}\text { Community health } \\
\text { nursing }\end{array}$ & 35 & 12.9 & 6 & 23.1 & 0 & 0.0 & \\
\hline & Gerontological nursing & 40 & 14.7 & 4 & 15.4 & 0 & 0.0 & \\
\hline & $\begin{array}{l}\text { Psychiatric and mental } \\
\text { health nursing }\end{array}$ & 42 & 15.4 & 4 & 15.4 & 0 & 0.0 & \\
\hline & Nursing administration & 35 & 12.9 & 5 & 19.2 & 1 & 50.0 & \\
\hline \multirow{7}{*}{$\begin{array}{l}\text { Numbers of academic } \\
\text { advising sessions } \\
\text { students received in } \\
\text { the current semester : }\end{array}$} & Non & 2 & 0.7 & 0 & 0.0 & 0 & 0.0 & \multirow{7}{*}{$\begin{array}{l}{ }^{\mathrm{Mc}} \mathrm{p}= \\
<0.001^{* *}\end{array}$} \\
\hline & One & 243 & 89.3 & 14 & 53.8 & 1 & 50.0 & \\
\hline & Two & 12 & 4.4 & 6 & 23.1 & 1 & 50.0 & \\
\hline & Three & 11 & 4.0 & 1 & 3.8 & 0 & 0.0 & \\
\hline & Four & 2 & 0.7 & 0 & 0.0 & 0 & 0.0 & \\
\hline & Five & 0 & 0.0 & 3 & 11.5 & 0 & 0.0 & \\
\hline & Six & 2 & 0.7 & 2 & 7.7 & 0 & 0.0 & \\
\hline \multirow{3}{*}{$\begin{array}{l}\text { academic advising } \\
\text { session: }\end{array}$} & Less than 15 minutes & 246 & 90.4 & 15 & 57.7 & 0 & 0.0 & \multirow{3}{*}{$\begin{array}{l}{ }^{\mathrm{Mc}} \mathrm{p}= \\
<0.001^{* *}\end{array}$} \\
\hline & 15 - 30 minutes & 26 & 9.6 & 9 & 34.6 & 1 & 50.0 & \\
\hline & More than 1 hour & 0 & 0.0 & 2 & 7.7 & 1 & 50.0 & \\
\hline
\end{tabular}

MC: Monte Carlo test

$\mathrm{P}>0.05 \Rightarrow$ Not significant, $* \leq 0.05 \Rightarrow$ significant, $* * \leq 0.01 \Rightarrow$ highly significant 
Quality of Academic Advising System

Table (5): The Relationship Between Socio- Demographic Characteristics of the Studied Nursing Faculty Members and their Perception of Quality of Academic Advising Level.

\begin{tabular}{|c|c|c|c|c|c|c|c|c|}
\hline \multirow{3}{*}{\multicolumn{2}{|c|}{ Socio-demographic characteristics }} & \multicolumn{6}{|c|}{ Quality of academic advising levels } & \multirow{3}{*}{$\begin{array}{c}\text { Test of } \\
\text { significance }\end{array}$} \\
\hline & & \multicolumn{2}{|c|}{ Low (28) } & \multicolumn{2}{|c|}{ Moderate (35) } & \multicolumn{2}{|c|}{ High (7) } & \\
\hline & & \multirow{2}{*}{ No. } & \multirow{2}{*}{$\%$} & \multirow{2}{*}{$\begin{array}{c}\text { No. } \\
10\end{array}$} & \multirow{2}{*}{$\%$} & \multirow{2}{*}{$\begin{array}{c}\text { No. } \\
2 \\
\end{array}$} & \multirow{2}{*}{ \% } & \\
\hline \multirow{4}{*}{ Age: } & $30<40$ & & & & & & & \multirow{4}{*}{${ }^{\mathrm{MC}} \mathrm{p} 0.328$} \\
\hline & $40<50$ & 9 & 32.1 & 10 & 28.6 & 0 & 0.0 & \\
\hline & $50<60$ & 8 & 28.6 & 7 & 20.0 & 1 & 14.3 & \\
\hline & $\geqq 60$ & 4 & 14.3 & 8 & 22.9 & 4 & 57.1 & \\
\hline \multirow{4}{*}{$\begin{array}{c}\text { Academic } \\
\text { position }\end{array}$} & professor emeritus & 4 & 14.3 & 7 & 20.0 & 4 & 57.1 & \multirow{4}{*}{${ }^{\mathrm{MC}} \mathrm{p} 0.349$} \\
\hline & Professor & 3 & 10.7 & 4 & 11.4 & 1 & 14.3 & \\
\hline & assistance professor & 8 & 28.6 & 8 & 22.9 & 0 & 0.0 & \\
\hline & Lecturer & 13 & 46.4 & 16 & 45.7 & 2 & 28.6 & \\
\hline \multirow{3}{*}{$\begin{array}{c}\text { Academic } \\
\text { experiences in } \\
\text { years }\end{array}$} & $10-19$ & 16 & 57.1 & 17 & 48.6 & 2 & 28.6 & \multirow{3}{*}{${ }^{\mathrm{MC}} \mathrm{p} 0.197$} \\
\hline & $20-29$ & 6 & 21.4 & 7 & 20.0 & 0 & 0.0 & \\
\hline & $30+$ & 6 & 21.4 & 11 & 31.4 & 5 & 71.4 & \\
\hline \multirow{9}{*}{$\begin{array}{c}\text { Area of specialty } \\
\text { : } \\
\text { (your } \\
\text { department) }\end{array}$} & medical surgical nursing & 4 & 14.3 & 11 & 31.4 & 2 & 28.6 & \multirow{9}{*}{${ }^{\mathrm{MC}} \mathrm{p}=0.073$} \\
\hline & critical care nursing & 5 & 17.9 & 1 & 2.9 & 0 & 0.0 & \\
\hline & nursing education & 0 & 0.0 & 3 & 8.6 & 1 & 14.3 & \\
\hline & pediatric nursing & 2 & 7.1 & 5 & 14.3 & 1 & 14.3 & \\
\hline & $\begin{array}{l}\begin{array}{l}\text { maternity } \\
\text { nursing }\end{array} \\
\end{array}$ & 5 & 17.9 & 2 & 5.7 & 1 & 14.3 & \\
\hline & " community health nursing & 5 & 17.9 & 4 & 11.4 & 1 & 14.3 & \\
\hline & gerontological nursing & 1 & 3.6 & 2 & 5.7 & 1 & 14.3 & \\
\hline & $\begin{array}{l}\text { psychiatric and mental health } \\
\text { nursing }\end{array}$ & 1 & 3.6 & 6 & 17.1 & 0 & 0.0 & \\
\hline & nursing administration & 5 & 17.9 & 1 & 2.9 & 0 & 0.0 & \\
\hline \multirow{2}{*}{$\begin{array}{c}\text { are you academic } \\
\text { advisor }\end{array}$} & Yes & 13 & 46.4 & 31 & 88.6 & 7 & 100.0 & \multirow{2}{*}{$\begin{array}{c}\chi^{2}=16.868 \\
\mathrm{p}=<0.001^{* *}\end{array}$} \\
\hline & No & 15 & 53.6 & 4 & 11.4 & 0 & 0.0 & \\
\hline \multirow{3}{*}{$\begin{array}{c}\text { Years as } \\
\text { academic advisor }\end{array}$} & None & 15 & 53.6 & 4 & 11.4 & 0 & 0.0 & \multirow{3}{*}{${ }^{\mathrm{MC}} \mathrm{p}=0.001^{*}$} \\
\hline & $1-4$ & 10 & 35.7 & 19 & 54.3 & 3 & 42.9 & \\
\hline & $5+$ & 3 & 10.7 & 12 & 34.3 & 4 & 57.1 & \\
\hline \multirow{4}{*}{$\begin{array}{c}\text { Number of } \\
\text { students assigned } \\
\text { to you for } \\
\text { advising }\end{array}$} & None & 15 & 53.6 & 4 & 11.4 & 0 & 0.0 & \multirow{4}{*}{${ }^{\mathrm{mc}} \mathrm{p}=0.003^{*}$} \\
\hline & $<20$ & 4 & 14.3 & 5 & 14.3 & 4 & 57.1 & \\
\hline & $20-25$ & 6 & 21.4 & 16 & 45.7 & 1 & 14.3 & \\
\hline & $26+$ & 3 & 10.7 & 10 & 28.6 & 2 & 28.6 & \\
\hline \multirow{2}{*}{$\begin{array}{c}\text { receiving } \\
\text { academic } \\
\text { advising training }\end{array}$} & yes "work shop" & 11 & 39.3 & 20 & 57.1 & 6 & 85.7 & \multirow[b]{2}{*}{${ }^{\mathrm{MC}} \mathrm{p}=0.063$} \\
\hline & No & 17 & 60.7 & 15 & 42.9 & 1 & 14.3 & \\
\hline
\end{tabular}

$\chi^{2}$ : Chi square test $\quad$ MC: Monte Carlo test $\quad \mathrm{P}>0.05 \Rightarrow$ Not significant, $* \leq 0.05 \Rightarrow$ significant, $* * \leq 0.01 \Rightarrow$ highly significant 


\section{References}

1. José S. Planning, Designing and Managing Higher Education Institutions. An International Seminar in California, 2005. Available at: http://www.oecd.org/edu/innovationeducation/34318472.pdf. (Retrieved on: 15/09/2012).

2. Freeman A. Institutional Change in Higher Education: Innovation and Collaboration. Published Research. 2011. Available at: http://Whitepaper Institutional-Change-in-Higher

Education-Hrabowkskifinal1.pdf

(Retrieved on: 27/10/2012).

3. Chua C. Perception of Quality in Higher Education. Ryerson University. Canada. 2004. Available at: http://citeseerx.ist.psu.edu/view.pdf.

(Retrieved on: 23/2/2013).

4. Nauta P. Omar P. Schade A. Accreditation Models in Higher Education. Helsinki University. Finland. 2004. Available at: http://www.enqa.eu/indirme/papersand-reports/workshop-andseminar/ENQAmodels.pdf. (Retrieved on: $25 / 10 / 2012$ ).

5. The Quality Assurance and Accreditation Handbook for Higher Education in Egypt. The National Quality Assurance and Accreditation
Committee in Collaboration with British Consultants in Higher Education. Egypt .2004.

6. Accreditation Manual for Post Secondary and Higher Degree Programs in Nursing. 2003. Available at: http//www.NLNAC.com. (Retrieved on: $25 / 10 / 2012$ ).

7. Steven D. Handbook of accreditation. 3rd ed. Chicago, 2003. Available at: http://www.unizg.hr/unesco/texts/litera tura/handbookofaccreditation.pdf. (Retrieved on: 22/8/2012).

8. A Publication of the Accrediting Commission for Community and Junior Colleges. Accreditation Reference Handbook. Accreditation Standards. $\underline{3}^{\text {rd }}$ ed. 2009. Available at: http://www.accjc.org/all-commissionpublications-policies. (Retrieved on: 22/8/2012.

9. Nash S. Results of the Accreditation Process to Guide Postsecondary Certificate-Granting Institution Improvement. Published Doctoral Dissertation. College of Education and Human Services .Marshall University, 2008.

Available at: http://mds.marshall.edu/cgi/viewconten t.cgi article $=1752 \&$ context $=$ etd . (Retrieved on: 4/3/2012). 
Quality of Academic Advising System

10. Penalber E. The Effectiveness of Student Support Services. Published Doctoral dissertation. Faculty of the Louisiana, State University. New York, 2005.

11. Virginia N, Wesley R, Thomas J. Academic Advising: A Comprehensive Handbook. $2^{\text {nd }}$ ed. New York: 2008.

12. National Academic Advising Association. Report on Statement of Core Values of Academic Advising. Published Report. 2009; 15(4):19-6. Available at: http://www.nacada.ksu.edu/Resources/ Clearinghouse/View-Articles/Corevalues-of-academic-advising.

(Retrieved on: 30/6/2012).

13. Beatty J. The National Academic Advising Association: A Brief Narrative History. NACADA Journal 2001; 11(1): 5-25.

14. Roger B. Developmental Academic Advising: What Do Students Want? NACADA Journal 1984; 4(1):5-13.

15. Winstor J. Evaluating Academic Advising: Manual for the Academic Advising Inventory. Development, Administration, and Scoring of the Academic Advising Inventory. The University of Georgia. USA, 2002.
16. Crookston B. A Developmental View of Academic Advising as Teaching. NACADA Journal 1972; 13(2): 12-7.

17. Oliver P. Faculty Perceptions of Student Academic Advising and Factors which Influence those Perceptions. Published Doctoral dissertation, University Of Denver. USA, 2000.

18. Jones L. An Evaluation of Academic Advisors' Roles in Effective Retention. Published Doctoral dissertation, Faculty Mentor and Chair, Capella University. New York, 2011.

19. Moses k. Philosophy of Academic Advising. The Role of the Academic Advisor at Coastal Carolina University. USA, 2010.

20. Kelly K, Cruise C. Advising Students on Academic Probation. Published Master thesis, Capella University. New York, 2002.

21. Don C, Wyatt J._Perception of Student and Academic Advisor about Academic Advising System. Published Doctoral dissertation,__Appalachian State University, New York, 2007.

22. Michel T. Advisor and advisee relationship and responsibilities. Published Doctoral dissertation, The 
Quality of Academic Advising System

Pennsylvania State University. New York, 2005.

23. Harrison S, Tiffin G. A Survey on Advisor Perceptions of the Academic Advising Program. Published Doctoral dissertation, University Of Alaska Anchorage. Alaska, 2011.

24. Herring S. Academic Advising Handbook. Responsibilities of Advises. $3^{\text {rd }}$ ed. Canada, 2012. Available at: http://www advising.unc.edu/First Year handbook/12-13fulladvisin. (Retrieved on: $15 / 5 / 2012$ ).

25. Murrill T. Academic Advisor Job Satisfaction and Implications for Student Satisfaction, Published Doctoral dissertation. University of Nebraska. Lincoln, 2005.

26. Boyle J. Student Impressions of Academic Advisor Efficacy. Published Doctoral dissertation. University of Nebraska. Lincoln, 2002.

27. Broadbridge A. Academic AdvisingTraditional or Developmental Approaches?: Student perspectives. British Journal of Guidance \& Counseling 2000; 24(1): 97-88.

28. White E. Student Advising Satisfaction and Academic Performance. Published master thesis. University of Massachusetts. Boston, 2000.
29. Kuhn T, Padak G. Is Academic Advising a Discipline? NACADA Journal 2008; 28(2): 2-4.

30. Andrepont K. Advising Perceptions in Student Support Services Programs. Published Doctoral dissertation. University of Southwestern Louisiana. Lafayette, 2005.

31. Carey S. Advising Satisfaction: Implications for First-Year Students' Sense of Belonging and Student Retention. Online article library. 2008. Available at http://dus.psu.edu/mentor//advisingsatisfaction/sthash.bPanMd50.dpuf. (Retrieved on: 2/10/2013).

32. McClellan J. Developing, Implementing, and Communicating Effective Mission Statements and Goals to Guide Advising Programs or Centers. An Academic Advising Journal 2007; 5(2):15-8.

33. Mayhall J \& Burg J. Solution-Focused Advising with the Undecided Student. NACADA Journal 2002; 22(1): 82-76.

34. Bloom J, Huston B. The Appreciative Advising Revolution. The online article library 2008. Available at: http://www.ni.edu/file_uploads/Apprec iative_Advising.pdf (Retrieved on: 26/6/2013). 
Quality of Academic Advising System

35. Nadler M. The Influence of Student Sex and Instructor Sex on Academic Advising Communication. Journal on Excellence in College Teaching 2002; 4(19): 40- 30.

36. Schulenberg J, Lindhorst $\quad$. Advising Is Advising: Toward Defining the Practice and Scholarship of Academic Advising. NACADA Journal 2008; 28 (1): 43-53.

37. Drake J. The Role of Academic Advising in Student Retention and Persistence. Published Doctoral dissertation. Indiana University. Bloomington, 2011.

38. Tahmoures A, Leo O. Pedagogical Issues Concerning Academic Advising. Journal of College Teaching and Learning 2006; 3(11): 25-44.

39. Glennen R. Selecting, Training, Rewarding, and Recognizing Faculty Advisors. Published Doctoral dissertation. University of South Carolina. Columbia, 2005.

40. Trombley T. An Analysis of the Complexity of Academic Advising Tasks. Journal of College Student Personnel 2009; 2(5): 23-9.

41. Stull N. Academic Advising: What Does it Mean at MU Today?. The online article library.2008. Available at:

http://www.nacada.ksu.edu/Resources/

Academic-Advising-Today/View-

Articles.aspx. (Retrieved on: 28/10/2013).

42. McLaren J. The Changing Face of Undergraduate Academic Advising. Guidance \& Counseling Journal 2004; 19(4): 17- 5 .

43. Wyckoff S. The academic advising process in higher education: History, research, and improvement. Recruitment \& Retention in Higher Education 2012; 13(1):1-3.

44. Miller T. Standards and Guidelines for Academic Advising. Council for the advancement of standards for student, 2009.

45. Schreiner L, Anderson E. StrengthsBased Advising: a New Lens for Higher Education. NACADA Journal 2005; 25(2): 10-3. 